\title{
ROOFTOP RAINWATER HARVESTING (RRWH) AT SPSV CAMPUS, VISNAGAR: GUJARAT - A CASE STUDY
}

\author{
Utsav R. Patel ${ }^{1}$, Vikrant A. Patel ${ }^{2}$, Manjurali I. Balya ${ }^{3}$, Harshad M. Rajgor ${ }^{4}$ \\ ${ }^{1}$ Lecturer, Civil Engineering Department, SPCE, Visnagar, Gujarat, India. \\ ${ }^{2,3,4}$ Assistant Professor, Civil Engineering Department, SPCE, Visnagar, Gujarat, India.
}

\begin{abstract}
India is land of versatile whether where inconsistency in rain is frequent. So as an option of having a back-up for water needs, one system becomes necessary which provides much saving of water; would be helpful in reducing wastage of water. Although rainwater harvesting $(R W H)$ is gaining popularity as a sustainable water saving system in urban as well as rural areas, estimating required storage area for water remains an important design challenge so we are going to design an effective plan by which we can collect rain water into a storage for a particular campus and we are also going to make a design by which we can collect water to the ground and use it for a domestic purpose. Present paper majorly focuses on Rooftop rainwater harvesting (RRWH) of the study area as Sankalchand Patel Sahakar Vidhyadham (S.P.S.V.) Campus, Visnagar. The prime objective of this paper is to fulfill the scarcity of the water in the campus and then it need to be use it for domestic \& drinking water supply.
\end{abstract}

Key Words: Rainwater, Runoff, Catchment area, Rainwater Harvesting System $* * *$

\section{INTRODUCTION}

Rain water harvesting is defined as the process of collecting and storing rain for later productive use. Rainwater harvesting is a mini-scale water resources project that collect stores rainwater by structural measures and regulates and make us use of it for domestic and production use. The term water harvesting refers to collection and storage of natural precipitation and also other activities aimed at harvesting surface and all other hydrological studies and engineering interventions aimed at conservation and efficient utilization of the limited water enforcement of a physiographic unit such as a watershed It is also defined as the process of collection and storing water from the area that has been treated to increase precipitation runoff.

A rainwater harvesting system comprises of components for - transporting rainwater through pipes or drains, filtration, and tanks for storage of harvested water. The common component of a rainwater harvesting system is shown below:

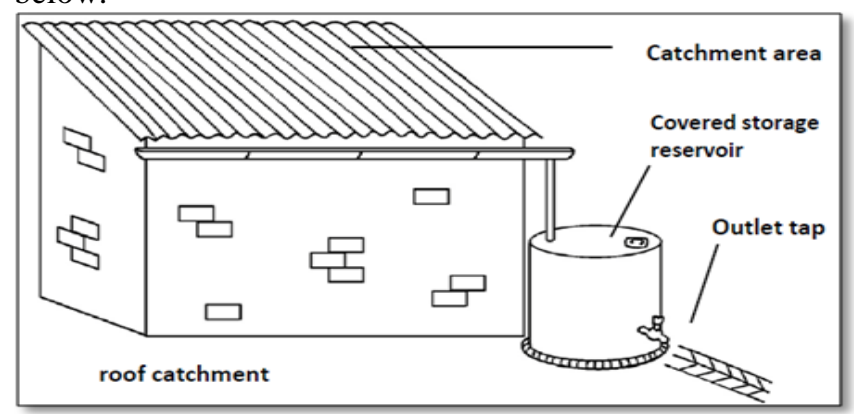

Fig-1: Schematic of a typical rainwater catchment system

(Source: UNEP IETC, 1998)

\section{OBJECTIVES OF THE STUDY}

$\checkmark \quad$ Analysis of present water use at S.P.S.V. Campus

$\checkmark$ Problems with current system

$\checkmark$ Goals, constraints and regulations

$\checkmark \quad$ Feasibility of rainwater collection system with recommendations

\section{METHODOLOGY}

\subsection{Determination of what the captured water be used for:}

We have done a rough estimate of demand, supply, and storage capacity may be sufficient. On the other hand, if rainwater is intended to be the sole source of water for all indoor and outdoor end uses, a more precise calculation have been ensure adequate supply.

\subsection{Determination of how much water can be captured:}

In theory, approximately 0.62 gallons per square foot of collection surface per inch of rainfall can be collected. In practice, however, some rainwater is lost to first flush, evaporation, splash-out or overshoot from the gutters in hard rains, and possibly leaks. Rough collection surfaces are less efficient at conveying water, as water captured in pore spaces tends to be lost to evaporation. Also impacting achievable efficiency is the inability of the system to capture all water during intense rainfall events. For instance, if the flow-through capacity of a filter-type roof washer is exceeded, spillage may occur. Additionally, after storage tanks are full, rainwater can be lost as overflow. 
For planning purposes, therefore, these inherent inefficiencies of the system need to be factored into the water supply calculation. Most installers assume an efficiency of 75 percent to 90 percent.

\subsection{Determination of the Collection Surface:}

The total catchment area will be calculating in this step and for that we will collect data related to all building of the campus.

\subsection{Calculation of the Volume of Rainfall:}

To ensure a year-round water supply, the catchment area and storage capacity must be sized to meet water demand through the longest expected interval without rain. If the rainwater harvesting system is intended to be the sole water source, the designer must seize the system to accommodate the longest anticipated time without rain, or otherwise plan for another water source, such as well backup or hauled water. Also, rainfall from high-intensity, short duration rainfall events may be lost to overflow from storage tanks or splash out from the gutters. Although these intense rainfall events are considered part of the cumulative annual rainfall, the total available volume of such an event is rarely captured. Another consideration is that most rainfall occurs seasonally; annual rainfall is not evenly distributed throughout the 12 months of the year. The monthly distribution of rainfall is an important factor to consider for sizing a system.

\section{STUDY AREA}

As discussed earlier in the section of introduction importance of rainwater harvesting at S.P.S.V. campus Visnagar, we clearly came to know the all the advantages which we can draw out by implementing this small but highly efficient technique in the campus. Thus to increase the potential, benefits of this system and draw maximum advantages from it, we need to have large rooftop areas which will be going to act as catchment areas. More the catchment areas more will be the surface runoff and thus more will be the amount of harvested water. Therefore as much as possible, we have included and considered all the major buildings having large rooftop areas. Hence, study areas includes all educational building, all hostels, Guest house and staff quarters Given below a satellite picture, showing majority of the buildings considered for rainwater harvesting system at S.P.S.V. campus VISNAGAR.

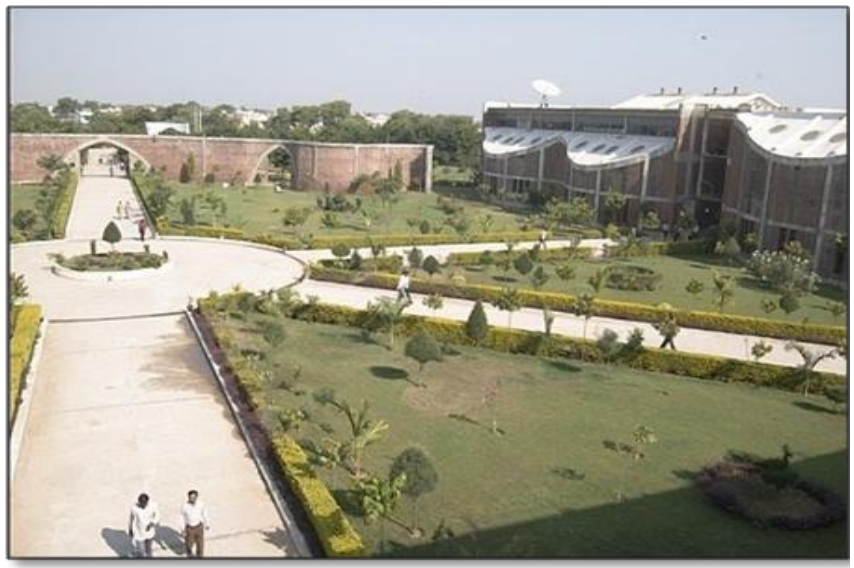

Fig-2: S.P.S.V. Campus Visnagar

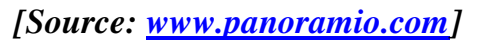

\section{DATA COLLECTION}

\subsection{Rainfall Data Collection}

Visnagar is located at $23^{\circ} 42^{\prime} \mathrm{N}$ longitude and $72^{\circ} 33^{\prime} \mathrm{E}$ latitude in Mehsana district of Gujarat at an elevation of about 117 meters (383 feet) above mean sea level. Visnagar has a semi arid climate and receives Medium rainfall during Southwest monsoon (June-September) and retreating southern east monsoon(December-January). Average annual rainfall ranges between $700-800$ $\mathrm{mm} /$ annum. The average monthly rainfall data are being taken from the Informatics Centre Thus rainfall data of the area related to campus is given below in the table no. 1 which is assumed to be same for the station of S.P.S.V. campus.

Table-1: Monthly Rain Fall Data of Mehsana District

\begin{tabular}{|l|c|c|}
\hline \multicolumn{1}{|c|}{ Month } & $\begin{array}{c}\text { Rain Fall } \\
(\mathbf{m m})\end{array}$ & $\begin{array}{c}\text { \% of Total } \\
\text { Rainfall }\end{array}$ \\
\hline January & 0.00 & $0 \%$ \\
\hline February & 0.00 & $0 \%$ \\
\hline March & 0.00 & $0 \%$ \\
\hline April & 0.00 & $0 \%$ \\
\hline May & 0.00 & $0 \%$ \\
\hline June & 62.10 & $15 \%$ \\
\hline July & 345.3 & $37 \%$ \\
\hline August & 281.4 & $22 \%$ \\
\hline September & 97.5 & $18 \%$ \\
\hline October & 0.00 & $0 \%$ \\
\hline November & 37.4 & $30.2 \%$ \\
\hline December & 0.10 & $0.96 \%$ \\
\hline
\end{tabular}

(Source: Meteorological Department, Gandhinagar)

\subsection{Determination of Catchment Area}

The rooftop surface area is nothing but the catchment area which receives rainfall. Catchment areas of the different buildings are measured. This measurement was done manually with the help of reinforced fiber tape which is the simplest technique known as tape survey. Before using the 
tape, tape was checked for any zero error and also length of the tape was also carefully checked for its accuracy. Given below the table for calculated the rooftop areas of all the buildings suited inside the campus.

Table-2: Calculation of Rooftop Area of All Building

\begin{tabular}{|c|c|c|c|c|}
\hline Building & \multicolumn{4}{|c|}{ Rooftop Area $\left(\mathrm{m}^{2}\right)$} \\
\hline Block No. & $\mathbf{A}$ & B & $\mathbf{C}$ & D \\
\hline $\begin{array}{l}\text { Degree } \\
\text { Department }\end{array}$ & 1685.43 & 2230.32 & - & - \\
\hline $\begin{array}{l}\text { Diploma } \\
\text { Department }\end{array}$ & 1115.16 & 976.5 & 545.0 & - \\
\hline Workshop & 976.5 & 558.0 & - & - \\
\hline Pharmacy & 570.28 & - & - & - \\
\hline $\begin{array}{l}\text { Post } \\
\text { Graduation }\end{array}$ & 630.0 & 630.0 & - & - \\
\hline $\begin{array}{l}\text { Dental } \\
\text { Department }\end{array}$ & 8730.28 & - & - & - \\
\hline MBA/MCA & 4467.5 & - & - & - \\
\hline Hostel & 745.0 & 745.0 & 745.0 & 745.0 \\
\hline $\begin{array}{l}\text { Sports } \\
\text { Complex }\end{array}$ & 223.2 & - & - & - \\
\hline Staff Quarters & 302.25 & 302.25 & 302.25 & 302.25 \\
\hline Guest House & 275.08 & - & - & - \\
\hline Hospital & 3037.85 & - & - & - \\
\hline Canteen & 502.20 & - & - & - \\
\hline TOTAL & \multicolumn{4}{|c|}{$31342.28 \mathrm{~m}^{2}$} \\
\hline
\end{tabular}

\subsection{Hydrological Analysis}

On the basis of experimental evidence, Mr. H. Darcy, a French scientist enunciated in 1865, a law governing the rate of flow (i.e. the discharge) through the soils. According to him, this Discharge Was Directly Proportional to Head Loss (H) and the area of cross- section (A) of the soil, and inversely proportional to the length of the soil sample (L). In other words,

$$
\mathrm{Q} \propto\left(\frac{\mathrm{H}}{\mathrm{L}}\right) \times \mathrm{A}
$$

$\mathrm{Q}=$ Runoff

Here, H/L represents the head loss or hydraulic gradient (I), $\mathrm{K}$ is the co-efficient of permeability

Hence, finally,

$$
\mathrm{Q}=\mathrm{K} \times \mathrm{I} \times \mathrm{A}
$$

Similarly, based on the above principle, water harvesting potential of the catchment area was calculated.

The total amount of water that is received from rainfall over an area is called the rainwater legacy of that area and the amount that can be effectively harvested is called the water harvesting potential. The formula for calculation for harvesting potential or volume of water received or runoff produced or harvesting capacity is given as :-

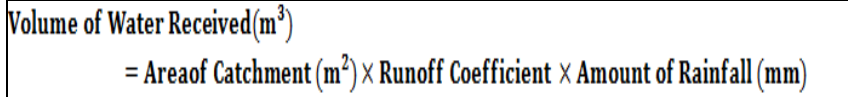

Runoff coefficient for any catchment is the ratio of the volume of water that runs off a surface to the volume of rainfall that falls on the surface. Runoff coefficient accounts for losses due to Spillage, leakage, infiltration, catchment surface wetting and evaporation, which will all contribute to reducing the amount of runoff. Runoff coefficient varies from 0.5 to 1.0 . In present problem statement, runoff coefficient is equal to 1 as the rooftop area is totally impervious. Eco-Climatic condition (i.e. Rainfall quantity \& Rainfall pattern) and the catchment characteristics are considered to be most important factors affecting rainwater Potential. Given below the table showing the value of runoff coefficient with respect to types of surface areas:-

Table-3: Value of Runoff Coefficient $(K)$

\begin{tabular}{|l|l|c|c|c|}
\hline No. & \multicolumn{1}{|c|}{$\begin{array}{c}\text { Types Of } \\
\text { Area }\end{array}$} & $\begin{array}{c}\text { Flat } \\
\text { Land } \\
(\mathbf{0 - 5 \%})\end{array}$ & $\begin{array}{c}\text { Rolling } \\
\text { Land } \\
\mathbf{( 5 - 1 0 \% )}\end{array}$ & $\begin{array}{c}\text { Hilly } \\
\text { Land } \\
(\mathbf{1 0 - 3 0 \% )}\end{array}$ \\
\hline 1 & Urban Area & 0.55 & 0.65 & - \\
\hline 2 & $\begin{array}{l}\text { Single Family } \\
\text { Residence }\end{array}$ & 0.3 & 0.3 & 0.3 \\
\hline 3 & $\begin{array}{l}\text { Cultivated } \\
\text { Area }\end{array}$ & 0.5 & 0.6 & 0.72 \\
\hline 4 & Pastures & 0.3 & 0.36 & 0.42 \\
\hline 5 & $\begin{array}{l}\text { Wooden Land } \\
\text { or Forest }\end{array}$ & 0.3 & 0.35 & 0.50 \\
\hline
\end{tabular}

(Source: Table 7.31, Irrigation Engineering \& Hydraulic Structure, by Garg, S.K.)

\subsection{Computation of Volume of Runoff per Year}

As we know the formula for runoff discharge from the reference is

\section{Volume of Water Received $\left(\mathrm{m}^{3}\right)=$ Area of Catchment $X$ Amount of Rainfall}

Total roof area of boy's hostel was calculated $=745.0 \mathrm{~m}^{2}$

Average annual rainfall at S.P.C.E. campus $=851 \mathrm{~mm} /$ year $=$ $0.851 \mathrm{~m} /$ year

Total volume of surface runoff water suppose to be collected $=745 \times 0.851=633.995 \mathrm{~m}^{3} /$ year 


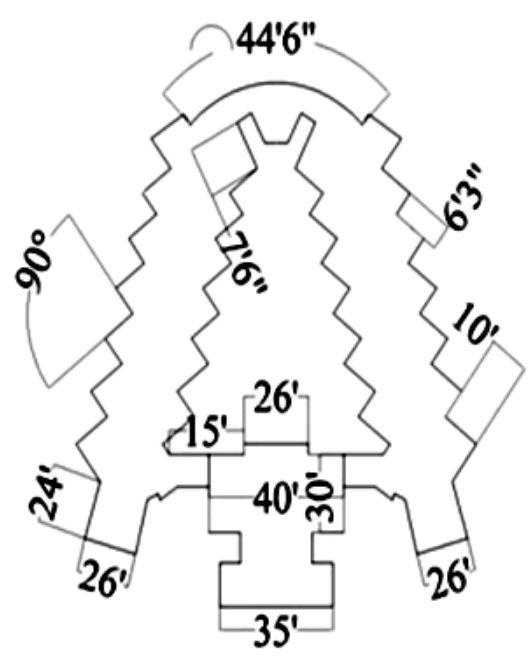

TOTAL ROOF AREA $=745 \mathrm{~m} 2(891.01258 \mathrm{Sq}$. yd $)$

Fig-3. Autocad Layout of Boys Hostel of S.P.C.E

Table-4: Showing Rainfall \& Discharge of Boy's Hostel Monthly At S.P.S.V. Campus

\begin{tabular}{|l|c|c|}
\hline \multicolumn{1}{|c|}{ Month } & $\begin{array}{c}\text { Rain Fall } \\
(\mathbf{m m})\end{array}$ & Discharge $\left.\mathbf{( m}^{\mathbf{3}}\right)$ \\
\hline January & 0.00 & $0.00 \mathrm{~m}^{3}$ \\
\hline February & 0.00 & $0.00 \mathrm{~m}^{3}$ \\
\hline March & 0.00 & $0.00 \mathrm{~m}^{3}$ \\
\hline April & 0.00 & $0.00 \mathrm{~m}^{3}$ \\
\hline May & 0.00 & $0.00 \mathrm{~m}^{3}$ \\
\hline June & 62.10 & $46.2645 \mathrm{~m}^{3}$ \\
\hline July & 345.3 & $257.2485 \mathrm{~m}^{3}$ \\
\hline August & 281.4 & $209.6430 \mathrm{~m}^{3}$ \\
\hline September & 97.5 & $72.6375 \mathrm{~m}^{3}$ \\
\hline October & 0.00 & $0.00 \mathrm{~m}^{3}$ \\
\hline November & 37.4 & $27.863 \mathrm{~m}^{3}$ \\
\hline December & 0.10 & $7.45 \mathrm{~m}^{3}$ \\
\hline
\end{tabular}

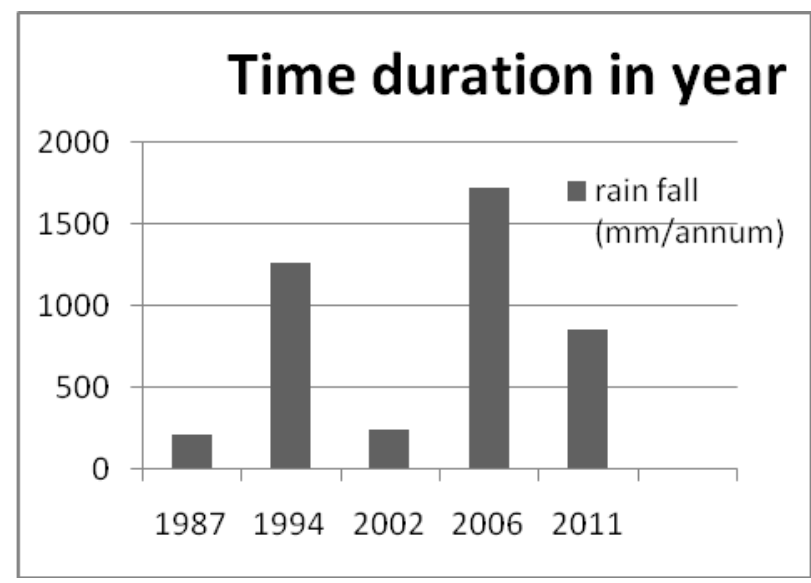

Chart-1: Amount of rainfall collected in through the last 20 years

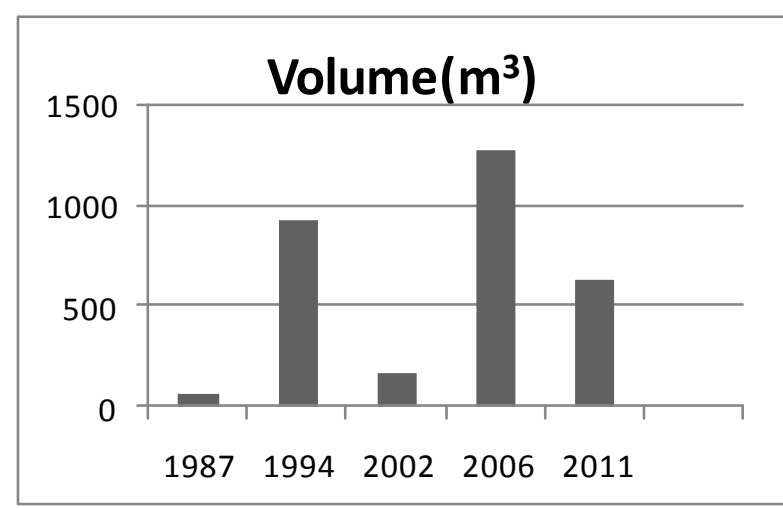

Chart-2: Volume of water collected from rain fall through the last 20 year

\subsection{Rainwater Harvesting Potential of Different} Building at S.P.S.V. Campus Visnagar

Earlier in the context, rainwater harvesting potential has been explained and dealt in brief in the earlier section Hydrological analysis. Hence, now the rainwater harvesting capacity of different building was found out with respect to same rainfall data. As the rooftop surface area of different building including hall of residence and different departmental building varies greatly with each other, thus amount of discharge produced or rainwater runoff produced will be different. With the small ideas of rainwater harvesting potential of different building, one can best take the advantage by of rainwater harvesting by building the system in the more potential building. Given below in the table no.8, the detail rainwater harvesting capacity of the entire campus buildings:

Table-5: Calculations of Catchment Area for all Buildings

\begin{tabular}{|c|c|c|c|c|}
\hline Building & \multicolumn{4}{|c|}{ Catchment Area $\left(\mathrm{m}^{2}\right)$} \\
\hline Block No. & $\mathbf{A}$ & B & C & D \\
\hline $\begin{array}{l}\text { Degree } \\
\text { Department }\end{array}$ & 1685.43 & 2230.32 & - & - \\
\hline $\begin{array}{l}\text { Diploma } \\
\text { Department }\end{array}$ & 1115.16 & 976.5 & 545.0 & - \\
\hline Workshop & 976.5 & 558.0 & - & - \\
\hline Pharmacy & 570.28 & - & - & - \\
\hline $\begin{array}{l}\text { Post } \\
\text { Graduation }\end{array}$ & 630.0 & 630.0 & - & - \\
\hline $\begin{array}{l}\text { Dental } \\
\text { Department }\end{array}$ & 8730.28 & - & - & - \\
\hline MBA/MCA & 4467.5 & - & - & - \\
\hline Hostel & 745.0 & 745.0 & 745.0 & 745.0 \\
\hline $\begin{array}{l}\text { Sports } \\
\text { Complex }\end{array}$ & 223.2 & - & - & - \\
\hline Staff Quarters & 302.25 & 302.25 & 302.25 & 302.25 \\
\hline Guest House & 275.08 & - & - & - \\
\hline Hospital & 3037.85 & - & - & - \\
\hline Canteen & 502.20 & - & - & - \\
\hline
\end{tabular}


Table-6: Calculations of Runoff for all Buildings

\begin{tabular}{|c|c|c|c|c|}
\hline Building & \multicolumn{4}{|c|}{ Runoff $\left(\mathbf{m}^{3}\right)$} \\
\hline Block No. & $\mathbf{A}$ & B & $\mathbf{C}$ & D \\
\hline $\begin{array}{l}\text { Degree } \\
\text { Department }\end{array}$ & 1434.30 & 1898.00 & - & - \\
\hline $\begin{array}{l}\text { Diploma } \\
\text { Department }\end{array}$ & 949.00 & 831.00 & 463.79 & - \\
\hline Workshop & 831.00 & 474.86 & - & - \\
\hline Pharmacy & 485.30 & - & - & - \\
\hline $\begin{array}{l}\text { Post } \\
\text { Graduation }\end{array}$ & 536.13 & 536.13 & - & - \\
\hline $\begin{array}{l}\text { Dental } \\
\text { Department }\end{array}$ & 7429.47 & - & - & - \\
\hline $\mathrm{MBA} / \mathrm{MCA}$ & 3801.84 & - & - & - \\
\hline Hostel & 633.99 & 633.99 & 633.99 & 633.99 \\
\hline $\begin{array}{l}\text { Sports } \\
\text { Complex }\end{array}$ & 189.94 & - & - & - \\
\hline Staff Quarters & 257.21 & 257.21 & 257.21 & 257.21 \\
\hline Guest House & 234.09 & - & - & - \\
\hline Hospital & 2585.21 & - & - & - \\
\hline Canteen & 427.37 & - & - & - \\
\hline TOTAL & \multicolumn{4}{|c|}{$26671.37 \mathrm{~m}^{3}$} \\
\hline
\end{tabular}

\section{SUMMARY AND CONCLUSION}

Campus detailing was done under this project and we have details below:

- Average annual rainfall ranges between 700-800 mm/annum.

- $\quad$ S.P.S.V. campus $=68.5$ acre $\left(277209.66 \mathrm{~m}^{2)}\right.$

- $\quad$ Total catchment area $=31342.28 \mathrm{~m}^{2}(7.745$ acre $)$

- $\quad$ Total quantity of rainfall $=26671.37 \mathrm{~m}^{3}$

Hence it was finally concluded that implementation of RAINWATER HARVESTING PROJECT to the campus of S.P.S.V. will be the best approach to fight with present scenario of water scarcity in all aspects, whether it is from financial point of view or from optimum utilization of land surface.

By implementation in water harvesting project in S.P.S.V. campus we can make little noble cause for rain water conservation which will be beneficial to the students of campus. It may also helpful to the campus. Our campus will become an example to others for rain water harvesting and if our campus would apply this than surely it will be in benefit. This paper fulfilled with all aspect of improving the water scarcity problem in the S.P.S.V. campus by implementing ancient old technique of rainwater Harvesting.

\section{REFERENCES:}

1) K. Venugopal and N. Ghosh (2010), "Rooftop Rainwater Harvesting at CWPRS, Pune; Maharastra A Case Study", Journal of Applied Hydrology, ISSN 0971-670N, VOL. XXIII, No. 1 \& 2.

2) Gould, J. and Nissen-Petersen, E. (1999), "Rainwater Catchment Systems for Domestic Supply", Intermediate Technology Development Group (I.T.D.G.) Publication.

3) S. K. Garg, "Hydrology and runoff computation, Irrigation Engineering \& Hydraulic Structure" Table 7.31 1987, pg. 674.

4) V. Jothiprakash and Madnar V. Sathe (2009), "Evaluation of Rainwater Harvesting Methods and Structures Using Analytical Hierarchy Process for a Large Scale Industrial Area", JWRAP, VOL. No. VI, PP. 427 to 438.

5) R. N. Athawale (2003), "Water Harvesting and Sustainable Supply in India", Centre for Environment Education, Ahmedabad, India.

6) Website Searched:

- http://rainwater.sustainablesources.com/

- http://www.harvestingrainwater.com/books/volume1/

- http://wiki.iricen.gov.in/doku/lib/exe/fetch.php?media =iricen_books:rain_water_harvesting.pdf

- http://www.rainwaterharvesting.org

- http://www.tn.gov.in/dtp/rainwater.htm

- http://www.aboutrainwater harvesting.com

\section{BIOGRAPHIES}

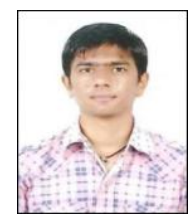

Utsav R. Patel

E-mail: utsavpatel.civil@gmail.com Contact: 9978428448

Vikrant A. Patel

E-mail:

vapatel.civil@spcevng.ac.in

Contact: 9998347014

Manjurali I. Balya

E-mail:

manjuralimomin1@gmail.com

Contact: 09714566993

Harshad M. Rajgor 